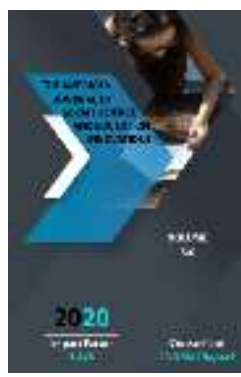

\title{
The Role Of Sufism Teaching In Spiritual Education Of Youth
}

Sobirova Zilolaxon Mahmudovna

Associate Professor Of Fergana State University, Fergana, Uzbekistan

Journal Website: http://usajournalshub.c om/index,php/tajssei

Copyright: Original content from this work may be used under the terms of the creative commons attributes 4.0 licence.

\section{ABSTRACT}

The article discusses the role of Sufism teachings in raising the spirituality of young people. The teachings of the Sufism of Central Asian thinkers have been philosophically analyzed.

\section{KEYWORDS}

Sufism, esoterism, “Dil ba yoru dast ba kor”, "Khush dar dam”, egoism, tarikat, culture.

\section{INTRODUCTION}

Thanks to the independence of the Republic of Uzbekistan, the sacred names of the great thinkers of Central Asia were revived, who made an invaluable contribution to the religious treasury of Islamic civilization and culture. The founder of one of the most significant directions (orders) of Sufism
Naqshbandiyya - Muhammad Jalaliddin (13181389) is also known in the Islamic world under the name Khoja Buzruk (great Khodja) Shahi Naqshband Balagardon [1]. His teaching and doctrine is devoted to the analysis of his travels, which were carried out in secret from the outer mind to the inner. According to his 
Sufiy theory, this doctrine is esoteric, that is, otherworldly, mystical doctrine, which is open not for every believer, but only for those who devote everything with a spiritual whole, as well as devote earthly life to the knowledge of truth.

\section{MATERIALS AND METHODS}

The teachings of Naqshbandiya were based on the ideas of the Javonmards. The great representatives of the Naqshbandi order, as well as the great thinkers of Central Asia, such as Abdurahman Jami, Alisher Navaiy, Ali Saydi, Muhammad Baki, Jahangir, the commander Amir Temur and Zahiriddin Muhammad Babur, have their own Islamic, ideological and divine principles and adhere to their own principles. As mentioned above, Islamic thought in Central Asia was one of the most widespread areas of mysticism. The famous thinker Yusuf Hamadoniy founded a school of imagination in the Turkestan region, and Ahmad Yassavi and many other thinkers of the Middle Ages grew up there.

Naqshbandiya has been one of the most popular teachings in the Muslim world since the rise of Islam to this day. The Naqshbandiya doctrine has deep historical, scientific and life roots. The mystical teachings of Bahavuddin Naqshbandiya included the following rules and instructions: - Naqshbandiya relied on hostility, Zoroastrianism and the eternity of ideas and traditions indicated in the Avesto, widespread Maverannahr;

- He did not deny the ancient TurkicBuddhist traditions, but included all their positive stories; - the universal nature of the Naqshbandiy teaching, which corresponds to Christian and mosaic religious and non-religious traditions;

- Economic, spiritual, religious and nonreligious traditions of the Ancient East:
Iran, China, India and Maverounnahr are humanistic;

- The most important is that the Naqshbandiya teachings are in the minds and thoughts of people directly related to the Islamic worldview and the practical traditions and heritage of Islam;

- The combination "Dil ba yoru dast ba kor", which is the motto of the Naqshbandiyya teachings in Khorasan, present day Central Asia and throughout the East, spreads throughout the Muslim world. The essence of this teaching is that you are always engaged in honest work, and if you remember Allah, then you will receive the blessing of two worlds from Allah;

- The teachings of Naqshbandiya unite the religious and non-religious heritage of the Eastern thinkers Imam Bukhariy, Imam Termeziy and Imam Motrudiy;

- Islamic-religious and scientific views of such saints as Yusuf Hamadaniy, Gijduvaniy, Ahmad Yassaviy, Najmiddin Kubro, Samaniy, Mir Kulola, Kusam Sheikh, Khalil Ata, were included in the content of the Naqshbandiy teaching;

- Naqshbandiya doctrine expresses local rural life and ideological, spiritual and scientific thinking. His teaching "Balogardon" was accepted as teaching about salvation from disasters; - ideological and political movements, such as "Ahlifutufat", "Zhuriy", "Sof Dilbirodar", "Javonmardiy" in Central Asia, recognized their basis on the holy teachings of Naqshbandi [2].

- According to historical sources, Said Muhammad Bahuddin Naqshband dates from 718 AD, August-September 1318, originally from Bukhara. The Naqshbandiy way of teaching has become widespread and recognized by the population due to its close proximity to the life of rural as well as craft families. The essence of this method 
is presented below the indicated eleven rahshads.

\section{RESULT AND DISCUSSION}

The theoretical foundations of these lines are set out in the Avesto: Sharia, Prophecy, Enlightenment and Reason, as well as the seven rules - koida: tawba, vaira, zuhid, fakr, sabr, tavvak and riya. The Sufi movement (order) of Naqshbandiya was quickly adopted simply by relatives and became a living principle due to the popularity of traditions, the similarity with their standard of living, and also becomes the main teaching of this direction:

- Firstly, "Khush dar dam" - according to this teaching, the world is divided into two parts: "foniy" (that is, changeable - ours) and "boqiy" (that is, eternal - in heaven). This world is transitory. Therefore, it is required to enjoy every moment of this limited world.

- Secondly, "Nazar bar kadam" - every step that takes place in a person's life must be controlled. This means that each person should understand, be aware of and manage their actions, watch their every step, every word and be trusted to Allah. It is argued that the self-control of each person over himself brings him closer to ideality.

- Thirdly. "Safar Dar Vatan" - this rule describes a person as "a traveler striving for the truth." His soul and body should be filled with the thought of pilgrimage. One of the most important pilgrimages in Islam is the pilgrimage on the way to Allah. Naqshbandi teachings call people to Hajj in order to purify them.

- Fourthly, "Khilvat dar anjuman" means isolation, loneliness, solitude.

- Fifth. "Yodkard" - Its meaning is that, according to the teachings of the Sufis, a person should spend his entire life with thoughts of Allah.

- Sixthly, "Bozgasht" - It means that human life is eternal, passing from one to another and ultimately turns into the eternal world.

- Seventh. "Nikohdosh" - it is indicated that a person should keep himself clean.

- Eighth, "Eddosht" is a constant reminder of joy and happiness.

- Ninthly, "Vukufizamoni" - every person, according to the Sufi conviction, should give every piece of his life in gratitude to Allah and do good;

- Tenth, the Naqshband Basics is a reference to holy prayers and words.

- Eleventh: "Vukufiadadi" - Sufi faith should be from the heart. A person who perfectly follows one of the ten rules of Naqshbandi storytelling will be perfect. The special recognition of the Naqshband teaching was recognized by the Asian people because of the content of prayers and the sacred rules of living in it. Man is the very accomplishment created by Allah. Thus, his existence is inextricably linked with God.

- The language and heart that Allah bestows on a person is only a blessing given to humanity. The work of Nakishbandiya "Honor God as beloved - but do not forget about work", or literally "Let your hands be in labor, and your soul given to the Almighty" is the prayer that is fixed primarily on Allah and on the human abilities of consciousness and hard work encourages people to work honestly and live his life Naqshbandiy glorifies the teachings of mankind calls him a beautiful creation in the face of adversity. Faith in humanity glorifies and calls upon the blessing given by Allah for good, for purity of thoughts, for happy everyday life and good deeds. One of the main occupations is described in this teaching: 
- predominance of honest work, living life by honest work;

- failure to make honest work a livelihood;

- doing business with the permission of Allah;

- respect for elders, respect for children, mercy for the homeless;

- be vigilant and pious to avoid pride, selfishness, giving alms;

- teaching Islamic teachings, Sharia rules, observance of hadith;

- Naqshbandiya is closely related to the foundations of Sharia.

It said, "If there are any mistakes in the Sharia, they will appear in Naqshbandiyah too."From the above statements and rules of the Naqshbandi doctrine, it is possible to draw ambiguous conclusions that these principles and pillars today are the main priorities in the spiritual and educational education of modern youth.

\section{REFERENCES}

1. M. Mamatov. Historical and philosophical essence of the Sufi doctrine. - T .: Islam Academy, 2018 .-- P.42.

2. Sadriddin Salim Bukhari. Bahauddin Naqshband or seven saints. - T .: Navruz, 2017 .- P. 128

3. Islamic encyclopedia. - T .: Shark, 2017 .-- P. 324.

4. The same literature - P.43 